\title{
Population Growth and Its Pressure on Available Natural Resources; the African Situation
}

\author{
Benson Polycarp and Ahmed Y. Ubangari, \\ Department of Urban and Regional Planning Nasarawa State Polytechnic, PMB 109, Lafia, Nasarawa State. \\ Nigeria, West Africa.
}

\begin{abstract}
The world population has been increasing despite measures for control; African situation seems to get worst in spite of researches available to her, the practicesfor use of such resources so far has been unsustainable. This paper looks at the stages of world population growth with attention on Africa, resource pressure with emphasis on land resources, water resources, food supply and how resources pressure led to biodiversity loss, pollution etc. and the need to identify that these things are not getting any better despite the global anthem on control and sustainable use of resources. It however concludes that African resources should not be seen as a curse to the continent, but it should copy from the mistake of the developed nations and set things right for the future generation so as to avoid the catastrophe thatbe felled the develop world and protect our common wealth.
\end{abstract}

\section{Introduction}

Global issues of population growth, urban concentrations,government policies, food supply situations, biodiversityloss, energy resources, pollutions, water resource situations etc.cut across the whole world except that the impact and reaction from African regions is different.Population growth or changes is an important component in physical planning, whether done consciously or unconsciously. African experiences tend to be on the negative because of negligence on the part of the people and government, poor management of resources by all, little or no forecast on resources use and control, poor technology, illiteracy and bad governance.

\section{WORLD POPULATION GROWTH}

From the last few decades, world population has grown rapidly. For example "from 1950 to 1980, the rate of population growth was most rapid in Latin America and Africa whose population more than doubled" (Allan and Anne, 1987). Table 1 show how population double in Latin America, Africa,East Asia and South Asia within just 30 years.

Table 1: Population of less develop world in millions

\begin{tabular}{|l|l|l|l|}
\hline & 1950 & 1980 & Population increase 1950-1980 \\
\hline Latin America & 164 & 364 & 200 \\
\hline Africa & 220 & 470 & 250 \\
\hline East Asia & 673 & 1175 & 502 \\
\hline South Asia & 716 & 1404 & 688 \\
\hline
\end{tabular}

Source: Allan and Anne, 1987

From table 1 above, it has shown that African population has increased from 220 million inhabitants to about 470 million people, showing and increase of about 250 million people in the span of just 30 years. Research has shown that from the $17^{\text {th }}$ century advance in sciences e.g. medicines, agriculture, industrialization etc. contributed seriously to population growth. From1650 to 1950,all continents share a fivefoldrise in population from about 500 million to about 2500 million people. The developing countries of the world have experienced tremendous increase in population growth. The UNPFA, (2007)has it that, "the developing countries of the world will account for 93\% of the world population growth from 2000 to 2030, while Africa alone will contribute $80 \%$ of the rate and rural population is expected to drop from 2005 to 2030 in developing countries, thus future population growth will be in towns and cities". This is evident on the rate of migration from rural to urban centres in search of better livelihood couple with availability of other facilities' even though such facilities could not go round the population. They are simply over stressed. "Today the world population stands at about 7billion and it is expected to hit 9.3 billion people by 2050"(UNPFA, 2007). Improvement in science and technology made it possible if not, "the system of hunting and gathering could not have allowed the survival of more than several millions of people" (Nathan and Kerstin, 1994). The problem however is that Africa has not been planning and projecting the need for additional facilities and services that will cater for this growing population. 
In Nigeria an attempt by the military regime to check population growth in the late 80 s and the early 90 s was thrown out by factors like religion, culture and to some great extend illiteracy.Illiteracy can make people feel given birth to more children is a security especially in the developing countries of Africa. Education for both genders is therefore an important tool in checking population. An example of poor gender practice is in the eastern part of Nigeria where more females take to education almost out numbering the male who are more engrossed in establishing businesses, while a serious contrast exist in the far north where female are rarely educated. Worst still in the far north, most female schools had to close down because of the advent of Boko Haram who oppose to western Education and go to such school to kidnap female student and force them into marriage in their camp. These are activities that retard technological growth and development in most African countries but encourage population growth in the midst of crisis. John (1998) state that the engine for demographic change is seems to be formal schooling rather than wide spread attainment of literacy without mass schooling and that movement towards mass schooling should not be confined only to the one particular gender.Education can assist people to make choices on the number of children to have or not to have.

Population increase is associated with so many problems which include pressure on the available resources like land, water supplies, food supplies, energy resource problems, others are biodiversity loss, pollution i.e.water pollution, land pollutions, air pollution leading to global warming, acid rains, droughtsetc.

\section{URBAN AND RURAL LAND RESOURCES}

As populations increase, the majority of African population moved to the urban centres in search of better standard of living. The world commission on Environment and development,(2009)State that by the turn of the century almost half of the population will live in towns and city centres. This will cause stress on the available infrastructure, services and shelter especially in developing countries of Africa and Asia. Furthermore, mining activities and other exploitation of resources in the rural areas has turn land into death spots, this is because too many things are going wrong in the mining sector in Nigeria for example despite huge potential that exist (Daily Trust, 2013). People mine land in search of mineral resources and at the end abandon such land to the detriment of the local community. Competition and conflicts over land has become common. The ability for earth's physical environment to support mankind varies. This is evident in Nigeria as community fight over piece of farm land, common in NasarawaState, Benuestate andTaraba State.Oseni (2013) reportedthat fighting on the border communities of Benue and Nasarawa states emerged as disputes between Fulani/Tiv as regards border demarcating farmland/ grazing areas which claimed many lives and farms, properties are also destroyed while many were rendered homeless. Other clashes over urban land can be seen in Kaduna, Bauchi and Jos and in all cases certain group of people want to have control over such piece of land. Other common cases of crisis on land in Africa are Rwanda, Burundi, Sudan,Zimbabweetc, while in the case of Zimbabwe land crisis has affected both economic and social life of the people and food insecurity has increased considerably since fast track land reform was implemented (Green,2004).

\section{WATER SUPPLIES}

Water is very important and critical to human, plant and animal survival.Only few governments in West Africa can provide their teaming population with clean water. The majority of the population still depend on river, pond, well and streams for their source of drinking water. Cities that have pipe born water is either inadequate or in a state of disrepair where water system leak and the resulting low water pressure allow sewage to seep into drinking water. An urban low income earner in Nigeria actually spend more on water vendor than the cost of paying if it were supplied by the water authority(Bashayi, 2011). A study also by Mason (1996), states that fresh water will relatively become scarce because of the impact of global warming and population growth which is expected to reach 10 billion by 2050 . What will actually happen to African growing population thereafter is best imagined.

\section{FOOD SUPPLY}

The capacity of major African countries to produce food tofeed its teeming population is getting out of hand. This is because intensive farming and used of herbicide has reduced the fertility of the soil.Poor farm practice which include continues cropping has drastically reduce soil fertility;couple with the fact that mechanised farming has not seriously gotten its footing in Africa. Other causes of food supply shortage are attributed to wars, drought, global warming etc. The Sudanese president has attributed the prevalence of bloodshed in Sudan to injustice shrouding the country as a result of drought and lack of rain (Daily Trust, 2013). Rapid population increase and poor economic planning are serious factor that the president refuses to mention which is not only common to Sudan but to most African countries.Places like Ethiopia also experienced terrible famine in 1984-1985" (Allan and Anne, 1987) and also the year 2012. Therefore food demand outweighs supply, that was why Ethiopia begged for foreign food aids and most African countries import food. To improve yield however, poor farming practice and exploitation of land most be replaced by a sustainable practice. 


\section{BIODIVERSITY LOSS}

Lots of animal and plant species are said to have vanished, while many others are at the brinks of being extinct.Developed countries of the world have statistics on biodiversity loss. Tim (2002) said biodiversity is reduced at a very substantial rate and that UK for example has lost 100 species in the last century and many more are in the sharp decline. Comprehensive data however on biodiversity lost in Nigeria for example is very rare.

The quest for man to physically develop and the need for more space because of population growth led to activities like clearing a large portion of land for farming, bush burning, lumbering, industrial sites, residential areas and Dams construction has displaced lots of micro and macro flora and fauna. Some of them couldn't adapt to other environment and therefore could not survive. Poor farming methods and grazing in northern Nigeria has exposed the soil to erosion and leading to desertification of such areas. Several programme to sustain the vegetation like tree planting campaign, organised grazing where introduced. The need to making sure that environmental impact assessment of every proposed project is carried out and outcome analysed to see if such impact is not detrimental to the environment and its habitat is important.

\section{ENERGY RESOURCES}

West Africa has lot of energy resource, ranging from solar energy, hydro plant, gas, oil lying in abundance but yet homes and worst still industry could not burst of 12 hours of uninterrupted public power supply. Rural dwellers and the low incomeearners are the worst hit because they could not have access; even if it is accessible definitely it will be beyond the reach of the ordinary man on the street. That was why rural and low income earners resort to the use of fire wood because the technology and the manpower to be able to harness these resources for the benefit of the people are not available. Whereas, UK government for example has targeted that $10 \%$ of electricity supply should come out of renewable sources by 2010 . There is need therefore for transfer of knowledge so that developing nations of Africa can highly maximised the resources at their disposal for the good of all. Table 2: shows an increase of $11.20 \%$ in achieving renewable energy target in the UK from 1996 to 2000. From the table below, the use of oil for example has reduced from 5\% in 1996 to $1.7 \%$ by the year 2000 . Therefore Africa needs to follow suit and invest more on renewable energy for $\mathrm{s}$ sustainable future.

Table 2:Target for renewable energy 1996-2000 in UK

\begin{tabular}{|l|l|l|}
\hline & 1996 & 2000 \\
\hline coal & $41.7 \%$ & $35.20 \%$ \\
\hline gas & $21.3 \%$ & $33.10 \%$ \\
\hline nuclear & $27.5 \%$ & $24.20 \%$ \\
\hline Other renewable & $11.00 \%$ & $22.20 \%$ \\
\hline oil & $5.00 \%$ & $1.70 \%$ \\
\hline Hydro (natural flow) & $0.40 \%$ & $0.50 \%$ \\
\hline
\end{tabular}

Source: Tim, 2002

\section{POLLUTION}

Aspopulation increase and man exploit the environment to achieve his goals of shelter, food and clothing, he actually generates waste that could be detrimental to him and the environment. Pollution occurs inthree major ecological components of the environment- land, water and air.

- Air pollution- smokes and gaseous emission from industries still represent the highest form of pollution. Other sources are particulates, sulphur dioxide, oxide of nitrogen, carbon monoxide,volatile organic compounds, polyaromatic hydrocarbons, toxic metals etc. the impact of this substances might not be on the immediate environment it is produced. "A variety of air pollutants is killing trees and lakes and damaging buildings and cultural treasures, close too and sometimes thousands of miles from point of emission, (the world commission on environment and development, 2009). Air quality issues and the depletion of ozone layer is still a major problem. African countries in its quest to industrialized are supposed to be thinking of mitigation measures even though their rate of air pollution and contribution to ozone depletion is low compared to the developed nations. Unfortunately for most African countries "globally, wealthier nations are better placed to financially and technologically cope with the effect of possible climate change" (world commission on environment and development,2009).Meaning that the impact will be hard hit on most African countries since research has shown that the impacts has no boundary.

Air pollutions are dangerous and can kill. Passed records have shown that so many people died of air pollution, even though the records did not cover Africa. In December 1952 for example, there were about 4000 death associated with pollution in London UK. It will not be surprise to state that some African countries today are within the stage of development of the UK in the 50s. The table 2:below shows record of death associated with air pollution. 
Table 3:Records of death associated with air pollutions

\begin{tabular}{|l|l|l|}
\hline Date & place & Excess death \\
\hline December 1873 & London, UK & $270-700$ \\
\hline February 1880 & London, UK & 1000 \\
\hline December 1892 & London, UK & 1000 \\
\hline December 1930 & Meuse valley, Belgium & 63 \\
\hline October 1948 & Donora, US & 20 \\
\hline December 1952 & London, UK & 4000 \\
\hline November 1953 & New York, US & 250 \\
\hline January 1956 & London, UK & 480 \\
\hline December 1957 & London, UK & $300-800$ \\
\hline November -December 1962 & New York city, US & 46 \\
\hline December 1962 & London,UK & $340-700$ \\
\hline December 1962 & Osaka, japan & 60 \\
\hline January -February 1963 & New York city, US & $200-405$ \\
\hline November 1966 & New York city, US & 168 \\
\hline
\end{tabular}

Source: After Elsom,1992:citedin Frank and Gordon 2003

- Land pollution- land itself can be polluted and also its underground water either through industrial effluent or domestic waste from residential homes. At organised places they are land filled while others are indiscriminately disposed. Population growth has also led to intensified use of the resources in Africa and occasioned the production of unwanted and harmful materials which are dump in the land. Oil spillages, seeping into underground and waste from industrial oil, are some causes of underground water pollution. This is very common in the oil producing areas of Niger-Delta which has led to the issues of resources control.

- Water pollution- causes by discharges into water-medium like river, lakes, streams etc. of industrial waste, sewage discharges, domestic waste, discharges from agricultural premises etc. its effect on water bodies is that it encourage excessive growth of oxygen consuming bacteria which diminish the availability of oxygen for other life in such water. This very common in the industrial areas of Lagos and the oil producing area of Nigeria etc.

\section{Conclusions}

It is evident that Africa is blessed with several resources, but crisis as a result of population increase, mismanagement, pollution and poor governance has brought about pressures on these resources by individuals through any means possible. While science and technology is good in saving life and reduced mortality rate it has also created problems that will probably take ages for African to solve. It is important for Africa to walk with nature and guide the resources they have jealously and sustainably and reduce the destructive tendencies on the environment as a result of it increasing population.

For Africa to be able to maintain its resource, Sustainable practices likepopulation control, water and food security, environmental protections are among some of the few important measures to take in achieving a liveable continent.

It is possible for Africa to use their resources, exploit or use the environment and create condition for the environment to replenish itself.Africa and other developing countries should take a cue from the developed world so that they don't repeat their mistakes.

Africans should also do away with activities that are disastrous to the environment and most important control birth to reduced and maintain consumption. Developed world on their part should sincerely transfer the knowledge they have so that our common world will be protected

\section{References}

[1]. Allan, F. and Anne, F., 1987. Population and Development in the Third World: Londonand New York. Routledge

[2]. Bashayi, O., 2011. Proposals for a Partnership Framework for Public Water Supply in Lafia Town: An unpublished M.Sc. theses submitted to the department of Urban and regional planning, Ahmadu Bello University Zaria. Nigeria.

[3]. Daily Trust. 2013. Sudan Presidents Admits Prevalence of Bloodshed, Injustice-Link Violence to Drought. 25 July, Page 26,

[4]. Gordon, M. andFrank., 2003. Air Pollution and Health in Developing Countries- The context. In: air Pollution and Health in Rapidly Developing Countries. Ed. Gordon, M. and frank, M.2003: London, Earthscan publications.

[5]. Green S. 2004. Zimbabwe land conflict. ICE case study. [Online] available at: http://www1.american.edu/ted/ice/zimbabwe.htm.

[6]. HamisuMuhammed 2013. Why Chines, Indians don't respect Nigeria mining laws.DailyTrust 31 July, Page 23.

[7]. John C.C., 1998. Mass education and fertility declined. In: population and development. Ed. Paul.D. and Geoffrey, M. London. Earthscanpublications Ltd

[8]. Mason C.C., 1996. Biology of Fresh Water Pollution: London. North American press

[9]. Nathan, k., and Kerstin L. K., 1994. The world population debate: Urgency of the problem. In: Population-the complex reality.Ed. Frances G.S.

[10]. Oseni L. 2012. Land Conflict among the Benue Nasarawa People, earth's right institutes [online] available at: http://course.earthrights.net/?q=node/440.

[11]. Tim C. 2002. Introductory Guide to Planning and Environmental Protection. London: The London royal town planning institute and Thomas Telford

[12]. The world commission on Environment and Development, 2009; Our common Future: Oxford. Oxford University press

[13]. UNPFA, 2007. State of the World Report 2007: Unleashing the Potentials of Urban Growth. (Online). Available at: http//www.unpa.org/wedav/site/global/share/document/publication/2007.pdf. Accessed on 06/10/13 